ORNLINURE Transients on the
The Effect of thermal Zircaloy Fuel Cladding
Hardness of

D. Hebron

Has th 
(1)

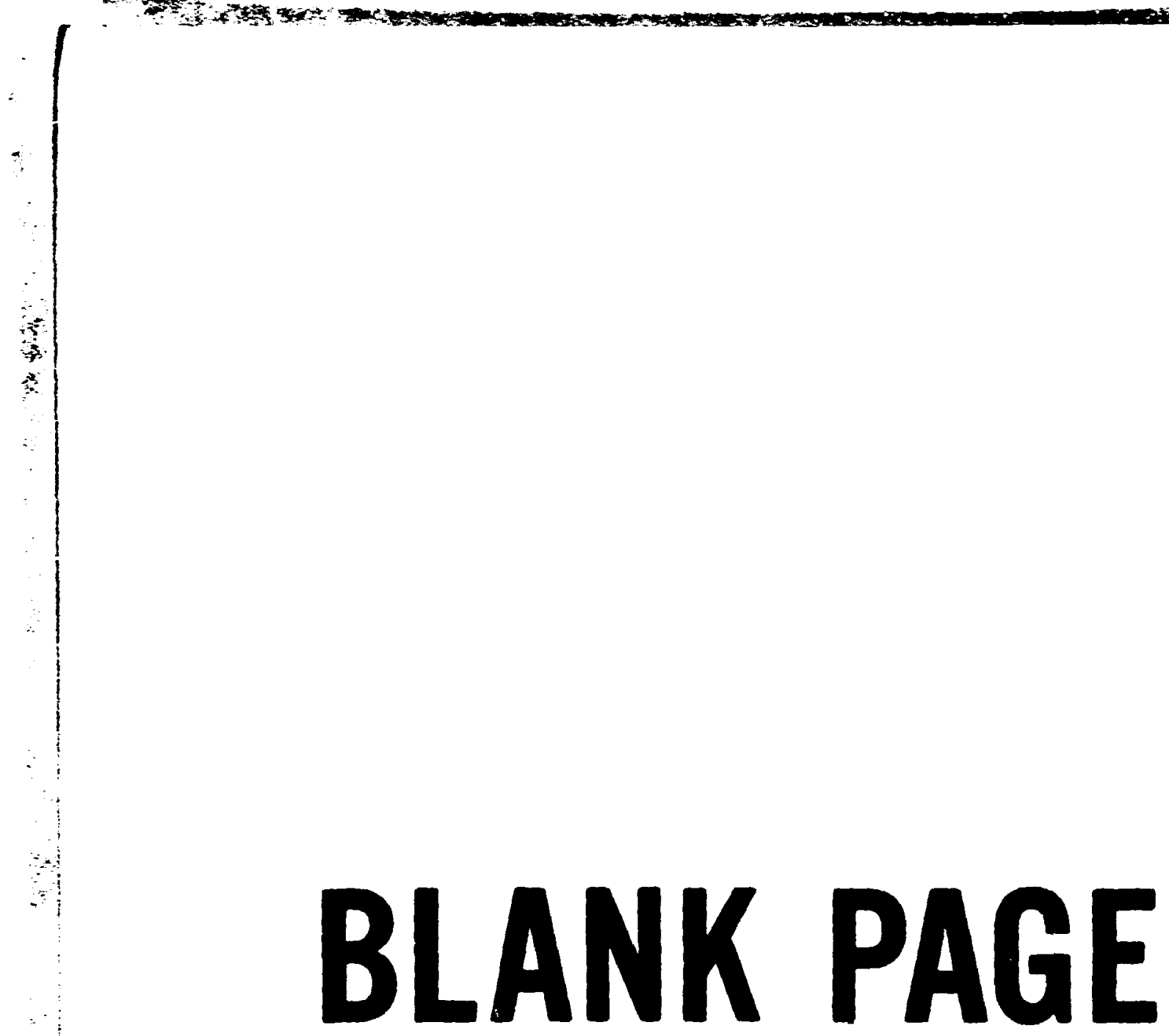




\begin{tabular}{|c|}
\hline Prinied in the United States of America. Availabte from \\
National Technical Information Service \\
U.S. Department of Commerce \\
5285 Port Royal Road. Springfieid. Virginia 22161 \\
Price: Printed Copy S3.50; Microfiche $\$ 2.25$
\end{tabular}

\footnotetext{
This report was prepered as an account of work sponsored by the United States Government Weither the United States nor the Energv Research and Devetopment Administration/Unitgd States Nucleap Regulatory Eommssion. nor any of ther employes. nor any of their contractors. sut ontractors, or their emplovets. mokes any warranty. express or implied. Or assumes any legal iabulity or responsibility for the accuracy. Completeness of usefuiness af any infor mation. apparatus, oroduct $x$ process disclosed, or represents tha: its use would not inffinge privately owned ights
} 


\author{
Contract :io. $\because-7 \$ 05-e n g-26$ \\ Work Performed Inder Subcentract \\ with Aerojet Nuclear Company \\ METALS AID CERAMICS DIVISION
}

\title{
THE EFFECT OF THERMAL TRANSIENTS ON THE HARDNESS OF ZIRCALOY FUEL CLADDIMG
}

D. O. Hobscis

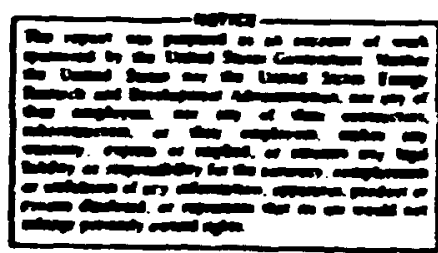

JUNE 1976

\footnotetext{
WOTice that socument conterm information of a dediminery noture

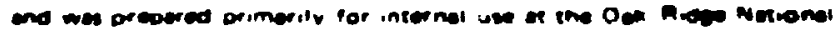

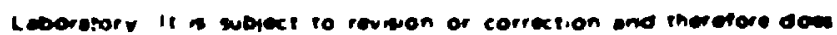
not reorcant a tinal ieport
}

\author{
OAK RIDGE NAT IOIAL LABORATORY \\ Oak Ridge, Tennessee 37830 \\ operated by \\ UNION CARBIDE CORPORATION \\ for the \\ ENERGY RESEARCH AND DEVELOPIENT ADMINISTRATION
}


THE EFFECT OF THEDAl TRUISIEITS ON THE HAPONESS OF ZIRCALOY FUEL CLADOIX

D. O. Hobson

AOSTRACT

This siudy is directed coward the deternination of the effects of annealing cycles with rapid heasing rateg, short hold $t$ thes at specific temperatures, and rapid cool-down rates on the hardness of 21 rcaloy fuel cladding. These rapid annealing cycles are designed to provide prellatinary annealing behavior data on Loss-of-Fluid-Test Reactor cladding sapples. Infcrmation has been obtained on 1. the tine dependence of the hardness as a function of annealing tepperature, and

2. a correlation of single- and multitranstent arsealing relationships.

Both single- and triple-cycle cransients were used; four hold tines at each of five maxima temperatures complsed the data set (each portion of the triple-cycle experiments had isothereal hold cices equal to one-third of their analogous single-cycle tines).

It was found that there vas little differeace in the hardness response between single- and triple-cycle transients for a given total hold tine at a particular teperature. Test teperatures range from 1000 to $1400^{\circ} \mathrm{F}$ ( 538 to $760^{\circ} \mathrm{C}$ ) and hold tines from 5 to $135 \mathrm{sec}$. The $1100^{\circ} \mathrm{F}$ ( $593^{\circ} \mathrm{C}$ ) level was found to be the transition level for hardness changes, with shorter times ( 5 and $15 \mathrm{sec}$ ) effecting litcle or no hardness decrease and the longer times (45 and $135 \mathrm{sec}$ ) producing partially and full; annealed acterial, respece ively. Temperatures equal to or greater chan $1500^{\circ} \mathrm{F}\left(704^{\circ} \mathrm{C}\right)$ resulted In fully annealed aterial for all hold thes. The $1000^{\circ} \mathrm{F}$ $\left(538^{\circ} \mathrm{C}\right)$ cests produced no measurable softening.

\section{INTRODUCTION}

The Loss-of-Fluid-Test Reactor (LOFT) is to be opersted by Aeroject Nuclear Company (NNC) to deternine, on a large scale, the effects of vartous sinrlated reactor accident situations. Since the fuel elesents of che LOFT reactor will undergo the thermal cycles invcived in the various test prograns, it is necessary to study their 

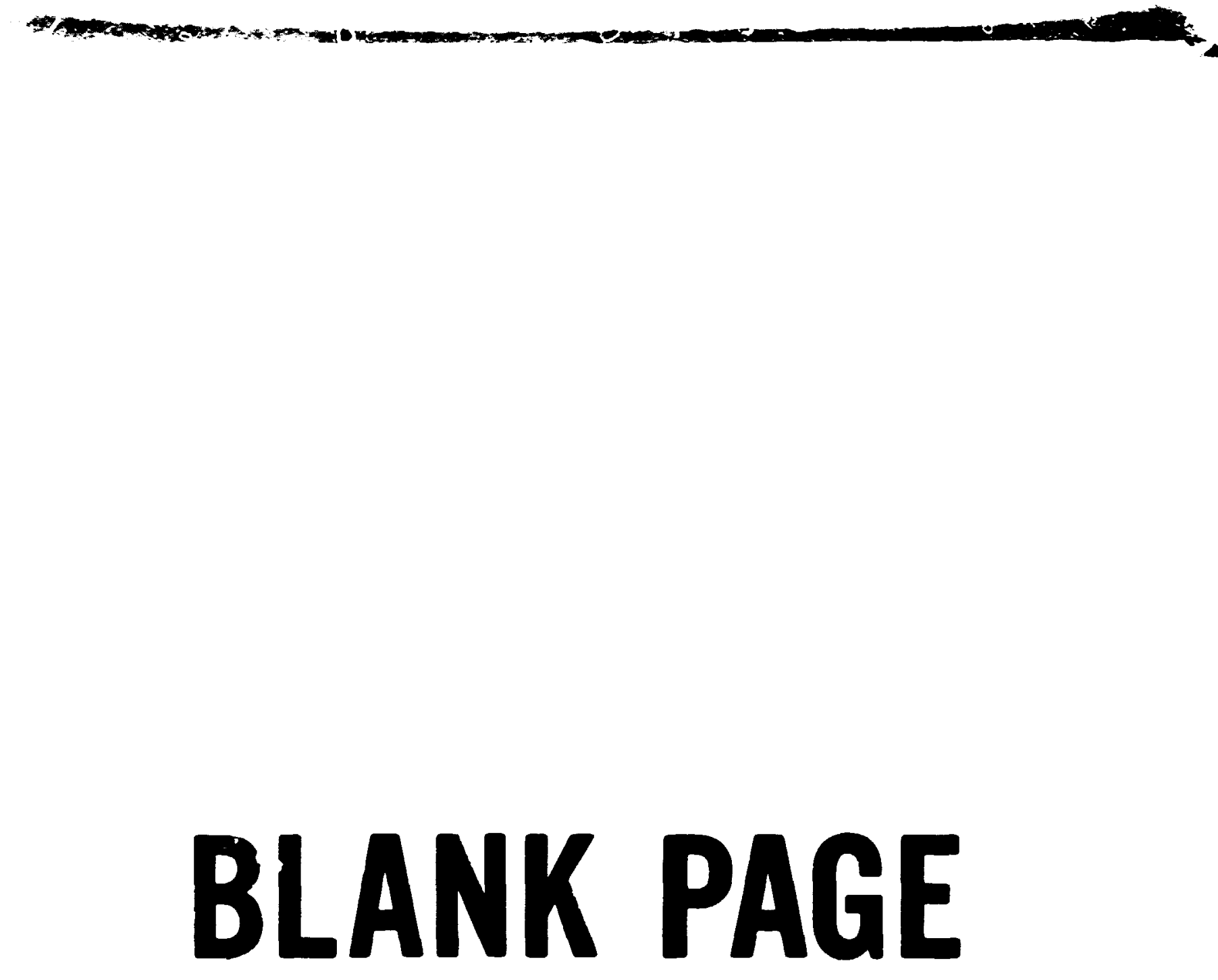
response to those cycles. The present study was designed to characterize, in a simple way, the effects of rapid theral cycles on the hardness of LOFT cladding. The hardness test, specifically the diano:d-pyranid acrohardness test, is a sensitive indicator of the metallurgical state of the clatding, and it can deteraine the cransition from the as-received, stress-relfeved state of the cladding to the fully annealed condition.

This study was designed to provide information on two aspects of the thermal response of LOFT cladding. The first involves the metallurgical response of the aterial to very short elevated-temperature exposures, which are preceded by rapid heat up and followed by a rapid $\operatorname{cool}$ down. What times at a specified teaperaturt. are sufficient to soften the Zircaloy cladaing, i.e., produce the annealed stace? The second aspect is concerned with the equivalency of temperature cycles. Do three cycles, each run for a tine, $t$, at temerature, produce the same softening as a single-cycle run for equivalent tine, $3 t$, at temperature?

The present study does not address a comprehensive range of the mechanical properties variables ti:at respond tn heat treatment; such vartables as yield and ultiate strengths, elongation, reduction in a-ea, etc. Rather, it exanines hardness only; but hardness is a valid indication in zircaloy, as in other materials, of the effects of annealing and recrystallization.

\section{EXPERIMENTAL DETAILS}

The tests in this study were performed on LOFT ruel cladding; Zircaloy 4 , with measured dimensions of $0.424-\mathrm{in}$. (10.8-an) 00 and 0.025 to $0.026-1 n$. (0.63 to $0.66-m)$ wall thickness. Ring specisens were cut with a lathe to $1 / 4-i n$. (6.3-am) lengths. The rings were then instrumented with Chromel-Alumel thermocouples spot-weided directly to the ring surfaces - one lead on the outer surface and one on the inner surface at the same axial and circumferential position.

The instrumented ring was positioned for thermal cycling by a C.24-1n. (6-m) OD quartz tube. The thermocouple iears, insulated with "two-hole" ceramic tubing, ran through the quartz and up through a slot 
in the quartz tube to their attachaent with the Zircaloy. The other end of th.e quartz tube was clamped to a sliding block that was positioned, at the inner range of its travel, by a micrometer stop adjustaent. Figure 1 illustrates the equipment setup. Heat for the thenal cycle was supplied by a Model 4085 ellipsoidal, radiant-heating furnace powered by a 750-W quartz-halogen lamp and manufactured by R-I Controls, a division of Research, Inc. The lasp was driven by manual control with a 10-A Variac. The furnace is destgned to reflect, scwewhat diffusely, the filament of the lam, located at one focus of the ellipsoid, into a seall volume located at the opposite focus. The longitudinal position of the hot spot was deternined by 2 temerature scan along the axis of the furnace at a constant, low powar level. This position was fixed by locking the atcrometer stop to linit the imward travel of the specinen.

Specimen temperature was monitored with a two-pen Hewlett-Packard chatt recorder driven at $0.2 \mathrm{in.} / \mathrm{sec}(5 \mathrm{~m} / \mathrm{sec})$ chart speed. One pen recorded specimen temperature and the other drew a constant-temperature iine at the required cest cenperacure and served as the reference line for manul control.

rpecinen cool down was achieved by withdrawing the specinen holder assembly from the furnace so that the sptrimen ring entered a stream of flowing argon gas. The furnace power was simultaneously turned off.

Three types of thermal cycling tests were used in this study. The first was a single-cycle transfent that involved a rapid, nomally $200^{\circ} \mathrm{F} / \mathrm{sec}\left(111^{\circ} \mathrm{C} / \mathrm{sec}\right)$, heat-up rate from $600^{\circ} \mathrm{F}\left(316^{\circ} \mathrm{C}\right)$ to the maxinum temperature and a rapid cool down to below $600^{\circ} \mathrm{F}$. The second involved three successive transients with heat-up and cool-down rates stailar to the single-cycle transient, but with the cool down after the first two cycles arrested as the temperature dropped below $600^{\circ} \mathrm{F}$ and reheat staried. The specimen was cooled to roow temperature after the third cycle. The total time at the maximum temperature for a particular triple-cycle specimen was made equal to the total tise at maxinum temperature for an analogous single-cycle specimen. 

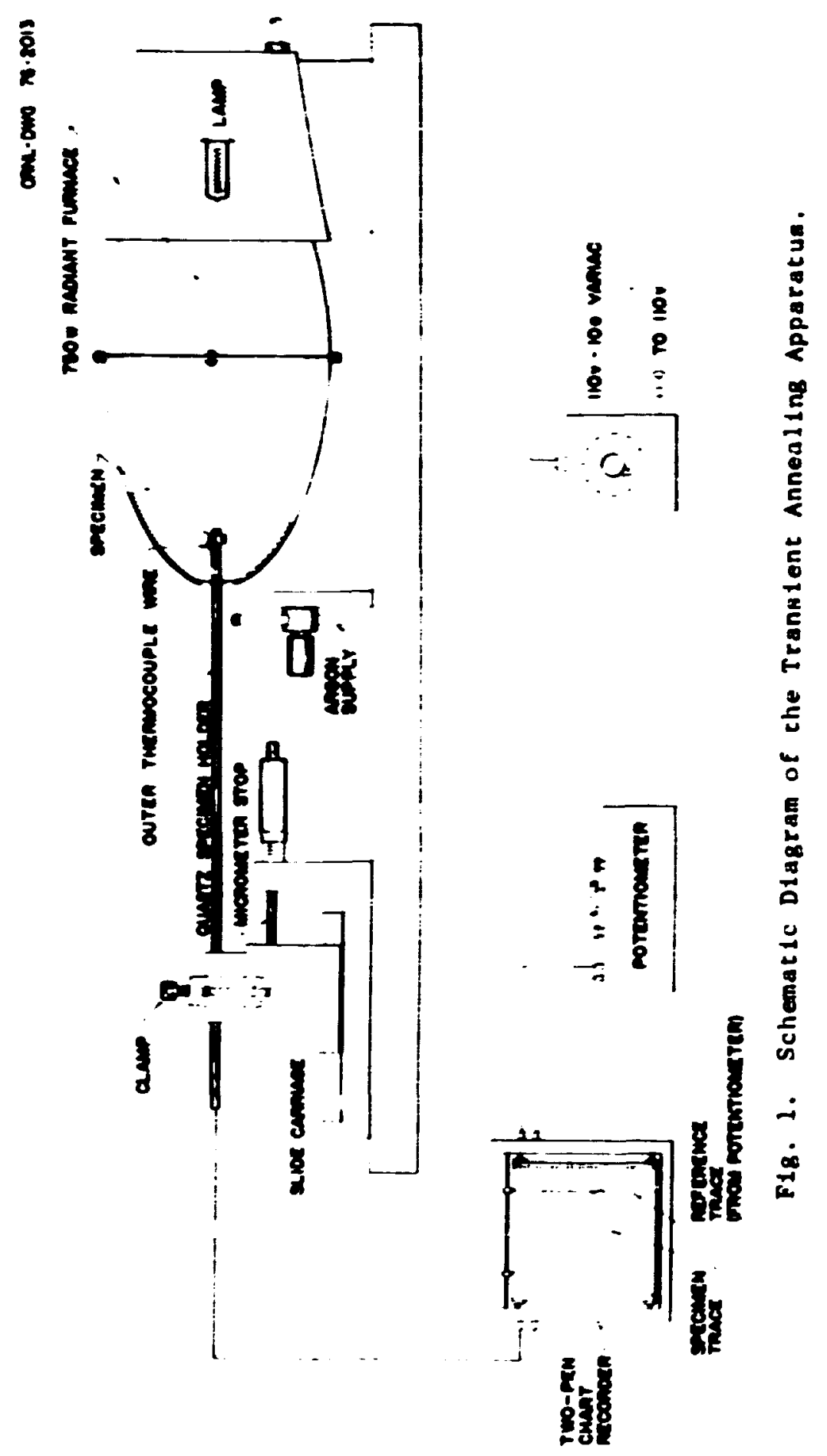
The chird type of test was essentially a "ihermal spike" cest in which a ring specimen was rapidly heated to a preselected tenperatire and indiately cooled from that temperature. Figure 2 illustrates the six

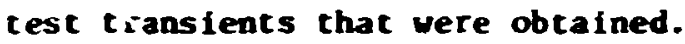

Cyciad specinens were wo:nted in epoxy, wet ground on 18u-chrough 600-grit pulishing paper and chenically polished with a 46:46:9 $\mathrm{H}_{2} \mathrm{O}: \mathrm{HNO}_{3}: \mathrm{HF}$ solution to resove cold work and provide an appropriate surface for the hardness impressions.

Hardness testing was performed with a: dimond-pyramid indenter with a 1-kg load. Initially, four miduall readings were taken from each ring, with the inpressicins spaced every $90^{\circ}$ fron the thernocouple attachment position. It was found later that the short-tine tests produced specimens with varying hardnesses in the circunferential direction dice to uneven heating rates that created temperature differences around the specinen. Hardness readings for these specinens wer: repeated and concentrated near the therecouple position - the position of aximu confidence in temerature.

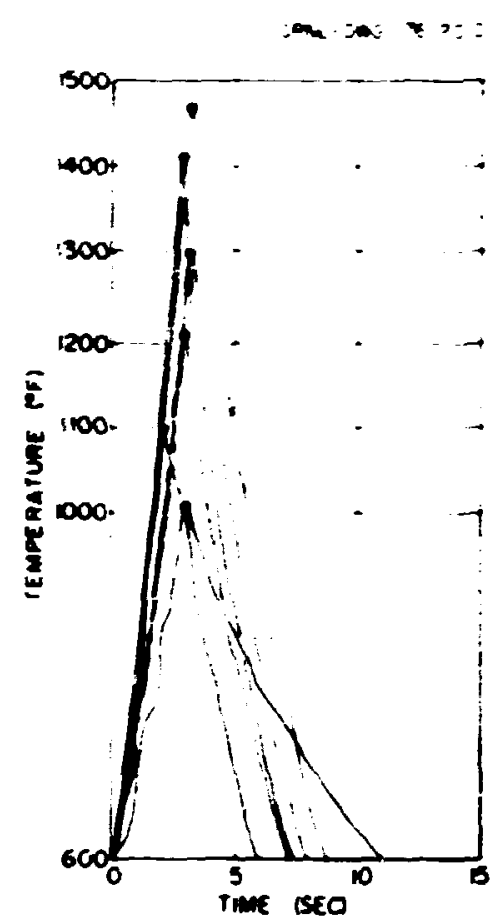

F1g. 2. Transient. Heating/Cooling Cycles with Zero Hold Iimes. 
In order to deternine tise extent of circuferential differences in heating rate and themal behavior within a singie specinen. a ring was equipped with wo thermoccuples, each with its leads attached to the inner and outer surfaces of the ring as before. One thernocouple held the ring it approxinately the sane spatial position occupied ity the previous test rings, and the other thermocouple ws attached $180^{\circ}$ around the ring. The ring was not in contact with the quartz tibe, but was heid by the feur thernocouple wires. Figure 3 lllustrates the thernocouple/ring geanetry and shows the temerature-tine relationships through two heating cycles. The solid curve represents the "control" thermocouple, the output of which was maitored to determine the manual setting of the powe: level to the furnace. The first cirve was obtained from an arbitrary cycle to approximately $1100^{\circ} \mathrm{F}\left(593^{\circ} \mathrm{C}\right.$; with a 5-sec nold $t$ se. The maxim difference between the tw sides of the ring was approxinately $\left.70^{\circ} \mathrm{F}{ }^{\prime} \prime g^{\circ} \mathrm{C}\right)$, with the auxillary thermocouple exhititing a faster themal response on both heating and cooling. The same specinen was then cycled with wore careful control for 45 sec at $1100^{\circ} \mathrm{F}\left(593^{\circ} \mathrm{C}\right)$. Again, the auxilfary thernocouple showed a core rapid thenal respronse under transient coaditions. However, under steady-stat $\geq$ conditions, the auxillary the rmoiouple showed a steady decrease in texperature relative to the "control" thernocouple.

Tne cause of this behavior is unknown, but a possible reason is a shifting of the hot zone of the furnace with tim at temperature. No measurewents of radial temperature variation vere made and it is posstble that the slightly off-center position of the specimen could have put it in a theral-gradient region. The hot-zone shift could be occasioned by movement of the lasp filament with tine.

\section{RESULTS}

The results of this study dewonstrate chat sigatficant annealing of the zircaloy tubes can occur in relatively short $r$ imes a: temperatures of $1200^{\circ} \mathrm{F}\left(649^{\circ} \mathrm{C}\right)$ and above. Table 1 ists the hardnesses that were obtained with the tabulated test conditions and Fig. 4 shc:'s the hardness results as a function of maximum nominal test cemperature. 


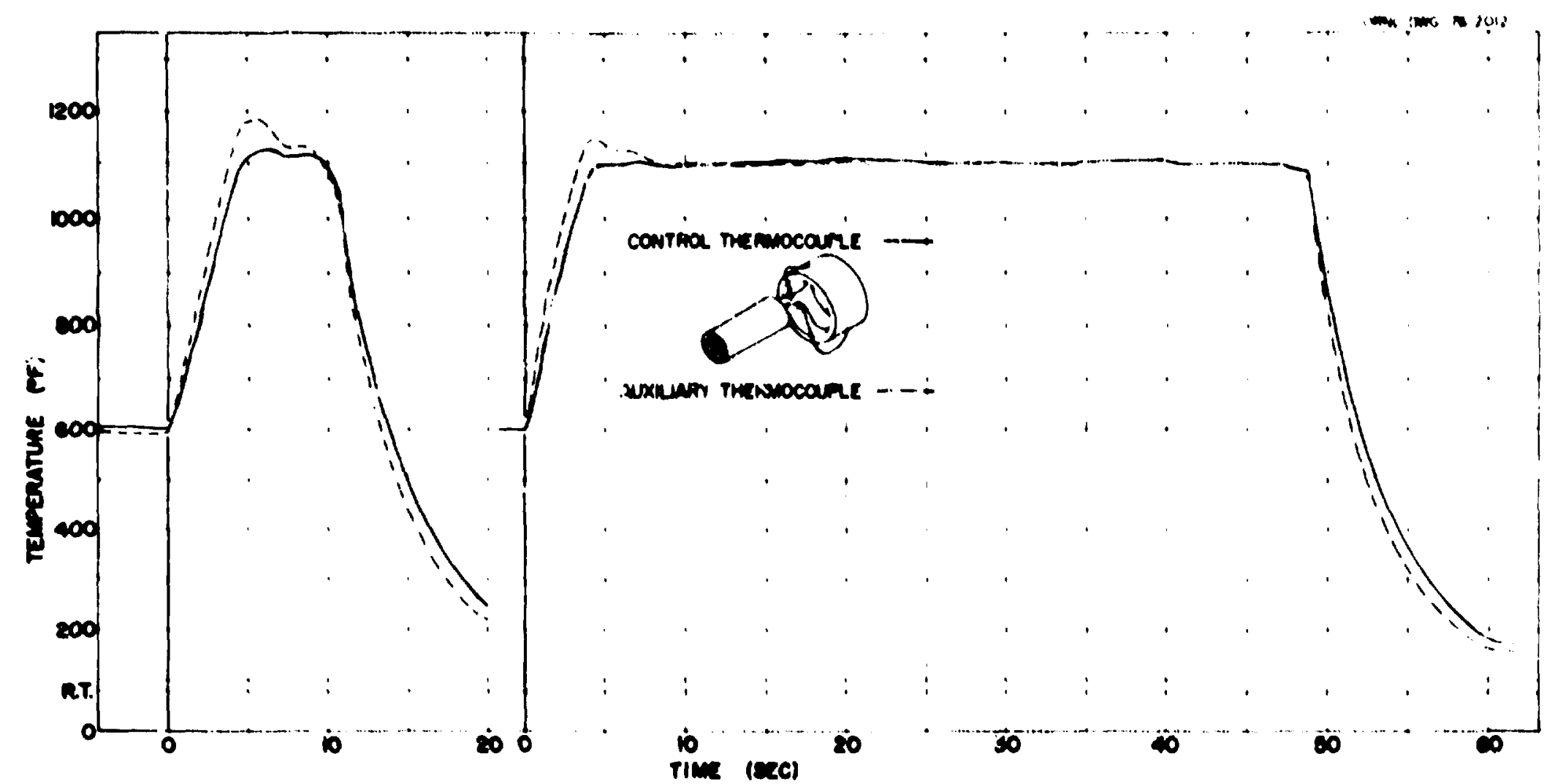

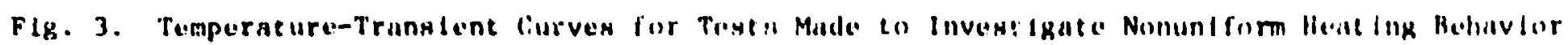
of Specimens. 
Table 1. Test Cond1tions and Results of Transient Testc

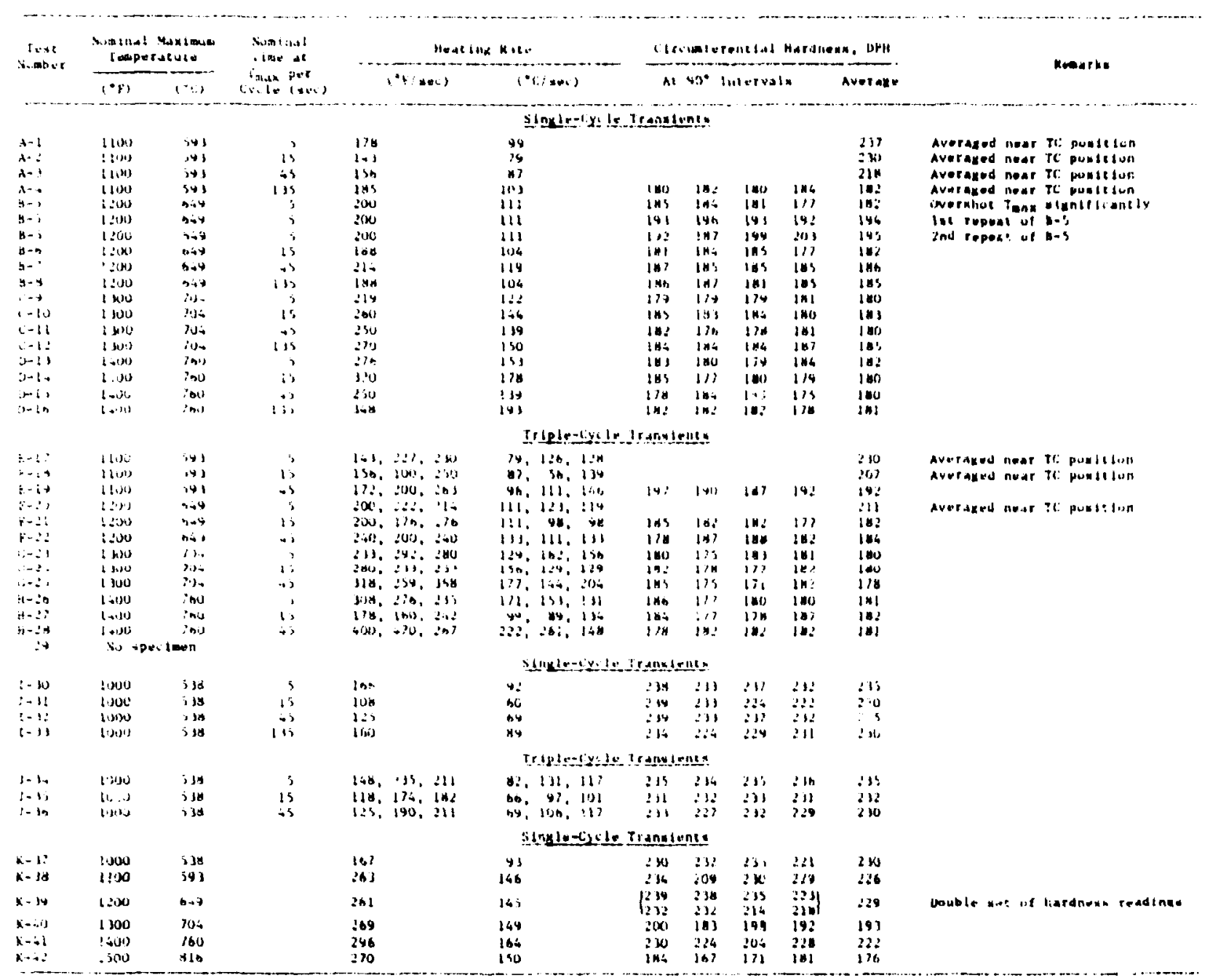




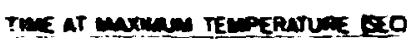

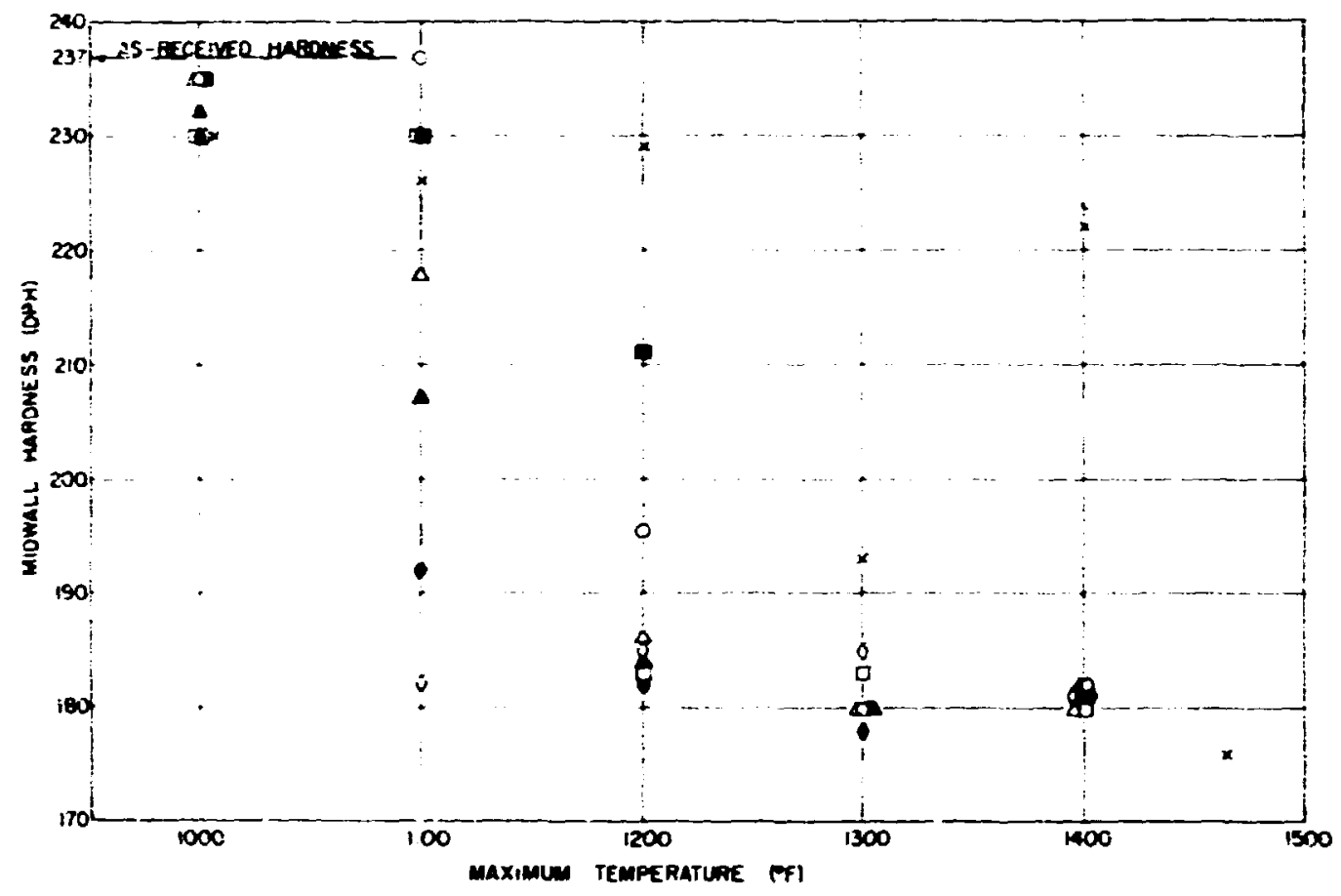

Fig. 4. Harciness Results for all Transient Tests in This Study.

The average hardness of the as-recelved material was measured to be $237 \mathrm{DPH}$. A11 tests conducted at a $1000^{\circ} \mathrm{F}\left(533^{\circ} \mathrm{C}\right)$ maximum temperature were found to have average hardnesses only slightly less than the asreceived material $(230-235 \mathrm{DPH})$. The $1100^{\circ} \mathrm{F}\left(593^{\circ} \mathrm{C}\right)$ maximum-temperature tests clearly showed typical annealing behavfor with the shorter test times producing little hardress drop (230-237 DPH) and the longer times producing almost fully softened material (132-192 DPH). Test: cycled to maximum cemperatures of 1300 and $1400^{\circ} \mathrm{F}\left(704\right.$ and $\left.760^{\circ} \mathrm{C}\right)$ were completely softened even after the minimum test times.

As seen in $F i_{c}$. 4, there is no obvious trend in the annealing behavior of the LOFT cladding when subjected to efther the single or the triple transient with equal total time at any particular maximum tomperature. It is felt that this resulted from the very rapid heat-up and cool-down rates employed in these tests. If slower rates had been 
used, it is probably that the integrated time-temperature ef fect would have been wre pronounced and that a triple-cycle transient would have resulted in a lower hardness than would the equivalent single cycle.

In addition to those tests in which specimens were held for specific tines at naxinu temperature, an additional set was run with zero hold tive (or as close an approxination as possible). The specimen was heated at a fast rate from $600^{\circ} \mathrm{F}\left(316^{\circ} \mathrm{C}\right)$ to the maximum temperature and, when it reached that temperature, was rapidly withdrawn into the gas strean for cooling. This resulted in a fast thereal spike. For instance, the $1400^{\circ} \mathrm{F}\left(760^{\circ} \mathrm{C}\right)$ test was heated at approximately $289^{\circ} \mathrm{F} / \mathrm{sec}\left(161^{\circ} \mathrm{C} / \mathrm{sec}\right)$ to $1410^{\circ} \mathrm{F}\left(766^{\circ} \mathrm{C}\right)$ and cooled at an average rate of $350^{\circ} \mathrm{F} / \mathrm{sec}\left(194^{\circ} \mathrm{C} / \mathrm{sec}\right)$ from 1410 to $1200^{\circ} \mathrm{F}\left(766\right.$ to $\left.649^{\circ} \mathrm{C}\right)$ and at a gradually decreasing average rate of $160^{\circ} \mathrm{F} / \mathrm{sec}\left(89^{\circ} \mathrm{C} / \mathrm{sec}\right)$ from 1200 to $600^{\circ} \mathrm{F}$. The entire test took $71 / 4 \mathrm{sec}$. The test series was run to maximan test temperatures of 1000 to $1465^{\circ} \mathrm{F}\left(538\right.$ to $796^{\circ} \mathrm{C}$ ). Figure 4 shows apparent inconsistencies in the results, with the 1300 and $1465^{\circ} \mathrm{F}$ (704 and $796^{\circ} \mathrm{C}$ ) specimens annealed and with the $1400^{\circ} \mathrm{F}\left(760^{\circ} \mathrm{C}\right)$ specimen only slightly softer than the as-received tubing. It is belleved that such variations resulted from slight differences in heating and/or cooling rates in temperature ranges where very rapid annealing is possible. No effort was made to ensure that the thermocouples were attached to the tube specimens at positions of equal wall thickness from specinen to specimen, nor was special effort made to position specimens in identical attitudes from test to test. Therefore, slight differences in heating rate could have existed undetected and cotild have exerted an influence on the material behavior. Although the chart recorder had rapid pen travel, it was still an electromechanical device ard could have missed some time-temperaturerelated detail near the peak turnaround temperature. It is apparent that the annealing response of the 21 rcaloy- 4 is quite a sensitive function of the experimental thermal "spike" conditions.

Finally, a discussion of heating rate 1:3 in order. The specimens in the tests were heated at a nominal rate of $200^{\circ} \mathrm{F} / \mathrm{sec}\left(111^{\circ} \mathrm{C} / \mathrm{sec}\right)$. It is clear that manusl control of furnace temperature is not the optimum method for effecting a constant heating rate from test to test. Rough 
estimates of the heating rates are listed in Table 1 ans vary from 100 to $470^{\circ} \mathrm{F} / \mathrm{sec}\left(56\right.$ to $\left.261^{\circ} \mathrm{C} / \mathrm{sec}\right)$. [The average rate for all cycles was $224^{\circ} \mathrm{F} / \mathrm{sec}\left(124^{\circ} \mathrm{C} / \mathrm{sec}\right)$.] The heating rates utilized in this study were sufficiently high :o cause no apparent effect on the annealing behavior. Several. of the lower rates occurred in the low-tenerature, short-tine transients and, as seen in Fig. 4, did not produce inconsistent resilts. For instince, the hardness of the $15-\sec 1100^{\circ} \mathrm{F}$ $\left(593^{\circ} \mathrm{C}\right)$ test $(\mathrm{A}-2)$, with a nominal iate of $143^{\circ} \mathrm{F} / \mathrm{sec}\left(79^{\circ} \mathrm{C} / \mathrm{sec}\right)$, is not different from the $3 \times 5 \sec 1100^{\circ} \mathrm{F}\left(593^{\circ} \mathrm{C}\right)$ test $(E-17)$, with nominal rates of 143,227 . and $230^{\circ} \mathrm{F} / \mathrm{sec}\left(79,125\right.$, and $\left.128^{\circ} \mathrm{C} / \mathrm{sec}\right)$. It appears that some scatcer in hardness values has resulted from the different heating rates as well as the temperature overshoot in some tests. However, closer control of the theraal conditions inthese tests would not be expected to change the overali hardness trends discussed above.

\section{ACKNOULEDGIENTS}

The author thanks E. B. Patton, who assisted in the experimentation, and Julla Bishop and Meredith Hill, who prepared and edited the manuscript. 